\title{
Retention of residual formaldehyde in treated Indian mackerel (Rastrelliger kanagurta) under iced storage and related food safety concern
}

\author{
LALY S. JAWAHAR, CHRISTY JOHN, MUHAMMED SHAFEEKH, T. K. ANUPAMA \\ AND T. V. SANKAR \\ ICAR-Central Institute of Fisheries Technology, P. O. Matsyapuri, Kochi - 682 029, Kerala, India \\ e-mail: lalyjawahar@gmail.com
}

\begin{abstract}
Indian mackerel Rastrelliger kanagurta dip-treated with different concentrations of formaldehyde $(0.2,0.5$ and $1 \%)$ was stored in ice along with untreated control fishes and evaluated the formaldehyde residue level as well as changes in $\mathrm{pH}$, total volatile base nitrogen (TVBN), aerobic plate count (APC) and sensory quality, during the 24 days storage period. Formaldehyde residue levels of $7.61 \pm 0.5,13.83 \pm 2.21$ and $20.7 \pm 2.02 \mathrm{mg} \mathrm{kg}^{-1}$ were recorded in $0.2,0.5$ and $1 \%$ treatments. Initial decrease in APC and its slow increase during storage was noticed. Shelf life of 18 days for 0.2 and $0.5 \%$ formalin treated fishes and 22 days for $1 \%$ treated fishes as compared to just 10 days in control fishes was observed. Marketed fishes with fresh appearance having higher values of TVBN, lower microbial load and with a higher formaldehyde residue can be considered as clear indications of formaldehyde treatment. Since fresh appearance of treated fishes can mislead the consumers, monitoring of formaldehyde residue, microbial and biochemical indices of ice stored fishes coming in markets needs to be undertaken in order to control marketing of fishes treated with the harmful chemical.
\end{abstract}

Keywords: Contamination, Food safety, Formaldehyde residue, Seafood

\section{Introduction}

Seafood forms an essential part of a healthy diet, but contamination of seafood can make it a potent source of food borne diseases. All over the world, consumers are becoming more health conscious and there is an increased emphasis for food which is nutritionally balanced as well as safe. For ensuring safe food to people, the commonly faced important issues among developed nations are quality and habitat concerns compared to product price and variation in income (FAO, 2009). In developing nations, the food gets contaminated with several harmful chemicals like formalin, dyes, insecticides and banned antibiotics. (Khan et al., 2009) along the marketing chain mainly due to anthropogenic activities posing health concerns to consumers. Marketing of seafood treated with formaldehyde, a listed potential cancer causing agent by the International Agency for Research on Cancer (IARC), has raised the consumer's consciousness regarding seafood safety. It is important to understand the level of formaldehyde residue and associated quality changes in treated fishes to provide important information on food safety.

Presence of formaldehyde in the levels ranging from 0.38 to $15.75 \mu \mathrm{g} \mathrm{g}^{-1}$ was reported in market samples by Noordiana et al. (2011). Yeasmin et al. (2010) have detected formalin in the range of 0.5 to $1 \%$ in imported samples of catla and rohu to Bangladesh. Department of Fisheries (DoF), Bangladesh reported presence of formalin $(0.5-1 \%)$ in the fish supplied to domestic markets (Yeasmin et al., 2010). Food Safety and Standards Authority of India (FSSAI) has been challenged by the uncontrolled usage of formalin in the domestic supply chain. Careless usage of formaldehyde by seafood vendors with an intention to prevent fish from spoilage and to increase storage time is an emerging safety issue of seafood.

Preparation of formaldehyde with a strength of $37 \%$ is known as formalin, which is unavoidable in laboratories and museums. It is a highly reactive chemical which is useful in industries of textile, paper, plastics and paint, both as disinfectant and preservative. It is often used in food for enhancing attraction of consumers, although it has many ill effects. It is a listed Group 1 carcinogen to humans by the International Agency for Research on Cancer. According to the United States Environmental Protection Agency (EPA), maximum reference dose (RfD) for formaldehyde is $0.2 \mu \mathrm{g} \mathrm{g}^{-1}$ body weight per day. At higher levels of exposure ( $>$ RfD), the chance for ill effects increases (Wang et al., 2007). A per EFSA 
(2014), human oral exposure from foods should not cross $100 \mathrm{mg}$ formaldehyde per day corresponding to 1.7 and $1.4 \mathrm{mg} \mathrm{kg}^{-1}$ body weight per day for 60 and $70 \mathrm{~kg}$ body weight respectively. The proposed limits of formaldehyde stipulated in Gadidae and Crustaceans by Italian Ministry of Health are 60 and $10 \mu \mathrm{g} \mathrm{g}^{-1}$ respectively, (Bianchi et al., 2007). Formaldehyde can develop in marine fish and crustaceans during post-mortem, from trimethylamineoxide (TMAO) due to the action of enzymes resulting in equimolar amounts of formaldehyde and dimethylamine (DMA) (Tsuda et al., 1988, Badii and Howell, 2002).

Treating with formaldehyde by dipping as a mode of preservation of fresh fish is illegal and can cause many health issues to consumers. Being bactericidal in nature, this chemical treatment can control spoilage in fish. However, residual levels of this chemical can lead to adverse effects upon human consumption. Since seafood is an important component of daily food of many people, intake of formaldehyde through fish can increase the risk and raise concern over human health. There are no reports available on the residual level of formaldehyde in fresh fish and formaldehyde treated fishes during ice storage and the associated biochemical, microbial and sensory changes. Hence a study was carried out to investigate the retention of formaldehyde in treated fishes along with quality characteristics during iced storage.

\section{Materials and methods}

\section{Sample preparation}

Fresh Indian mackerel (Rastrelligar kanagurta) with an average length of $15 \pm 0.96 \mathrm{~cm}$ and average weight of $54.4 \pm 9.17 \mathrm{~g}$ were procured from the Kalamukku landing centre, Ernakulum. The samples were immediately iced (1:1 fish to ice) and transferred to the laboratory in insulated boxes. The samples were divided into 4 separate lots. The control lot was immediately iced in 1:1(fish to ice) ratio in an insulated box. The other three lots were treated with formaldehyde, $0.2,0.5$ and $1 \%$ solutions, prepared from the commercial solution of formaldehyde (Merck, 37\%), by dipping for $10 \mathrm{~min}$ (Treatment level used in the present study was selected as per the market situation of 0.5 to $1 \%$ formaldehyde). The treated samples were drained and iced again in the same ratio in insulated boxes. Samples were stored in a chilled room at $4 \pm 2^{\circ} \mathrm{C}$. The boxes were filled with ice on alternate days to compensate for the melting of ice. Sampling was done every alternate day till 24 days of storage. Eleven fish samples were taken from each lot; muscle from six was homogenised for chemical analysis, three were used for microbiological analysis and two fishes were taken for sensory analysis by the sensory panel members.

\section{Formaldehyde determination}

Formaldehyde estimation was done as per the method of Castell and Smith (1973). For this, $10 \mathrm{~g}$ fish meat was homogenised with $10 \% \mathrm{w} / \mathrm{v}$ trichloroacetic acid for one minute. The extract was centrifuged and $5 \mathrm{ml}$ of supernatant was collected and added to $15 \mathrm{ml}$ distilled water taken in a beaker, made up to $25 \mathrm{ml}$ after adjusting the $\mathrm{pH}$ to 6 (using $45 \%$ sodium hydroxide), and filtered using filter paper. For the test, $5 \mathrm{ml}$ of the filtrate was mixed with $5 \mathrm{ml}$ of double strength Nash reagent (DSNR), heated at $60^{\circ} \mathrm{C}$ for $5 \mathrm{~min}$ and the absorption was measured at $415 \mathrm{~nm}$ using an UV/VIS spectrophotometer (Thermo Scientific UVI).

\section{Biochemical analysis}

$\mathrm{pH}$ was measured using a digital $\mathrm{pH}$ meter (Hanna instruments, HI 2221 pH/OHP meter) after blending $4 \mathrm{~g}$ of sample with $40 \mathrm{ml}$ of distilled water (AOAC, 1990). Estimation of total volatile base nitrogen (TVB-N) was done by the micro diffusion method (Conway, 1950).

Aerobic plate count (APC)

Fish meat sample (125 g) was weighed into a stomacher bag, $225 \mathrm{ml}$ of sterile phosphate buffer was added and blended for $2 \mathrm{~min}$ at $200 \mathrm{rpm}$. Serial decimal dilutions of sample homogenate were prepared using sterile buffer. Aerobic plate count was determined using plate count agar at an incubation temperature of $37 \pm 2^{\circ} \mathrm{C}$ for $48 \mathrm{~h}$ (USFDA, 2001).

\section{Sensory analysis}

Sensory evaluation was carried out by a panel of five experts. Sensory scoring was done using a 9-point hedonic scale as detailed by Amerine et al. (1965). Assessment was based on appearance, colour, odour, flavour, taste and texture (like extremely -9 to dislike extremely -1 ). Scoring system used was: 9-7 (no off-flavour, bright colour, firm and elastic nature), 7-5 (trace off-flavour, pale to colourless and elastic nature) and 4-5 (medium off-flavour, slight brownish colour and soft texture). An overall acceptability score was calculated based on the sum of scores obtained for raw and cooked fish meat, a score of four was considered as the border line of acceptability.

\section{Statistical analysis}

Analysis of variance (ANOVA) was carried out using statistical software SPSS.16 (SPSS Inc. Chicago). All the tests were performed in triplicate $(n=3)$. Results are given as mean \pm standard deviation. The statistical significance was noted at $95 \%$ confidence level $(\mathrm{p}<0.05)$. 


\section{Results and discussion}

\section{Residual level of formaldehyde}

The content of formaldehyde in the control and formalin treated samples on alternate days is given in Table 1. Sample treated with $1 \%$ formaldehyde showed a residual level of $20.7 \pm 2.02 \mathrm{mg} \mathrm{kg}^{-1}$ just after treatment, while 0.5 and $0.2 \%$ treatment resulted in a residual level of $13.83 \pm 2.21 \mathrm{mg}$ $\mathrm{kg}^{-1}$ and $7.61 \pm 0.50 \mathrm{mg} \mathrm{kg}^{-1}$, respectively. Significantly higer $(p<0.05)$ levels of residual formaldehyde was observed in treated samples as compared to control. Also, a statistically significant difference $(p<0.05)$ in formaldehyde content among treatments was observed with increasing levels noted with increase in concentration of formaldehyde treatment. Formaldehyde concentration showed a significant decrease in formalin treated samples during storage and it can be attributed to leaching out of formaldehyde along with melted ice water as it is water soluble. Yeasmin et al. (2013) pointed out that treating fish at greater levels of formalin demands prolonged washing period either by immersing in water or ice. They reported that formalin removal was higher in case of water immersion than icing because of its water-soluble nature. In the case of control samples also there was a gradual reduction during ice storage, possibly due to binding to proteins which can result in changes in both conformational and functional properties. Simeonidou et al. (1998) reported increase in formaldehyde content during ice storage while a reduction was noticed in the case of ice storage of species such as Atlantic mackerel and striped mullet. On the final day of storage $\left(24^{\text {th }}\right.$ day), formaldehyde concentration of $0.42 \pm 0.002 \mathrm{mg} \mathrm{kg}^{-1}$ was observed in $1 \%$ treated samples. In the case of 0.5 and $0.2 \%$ treated samples, the final residual level on the day of sensory rejection $\left(20^{\text {th }}\right.$ day) was $0.49 \pm 0.10$ and $0.35 \pm 0.30$ $\mathrm{mg} \mathrm{kg}^{-1}$ respectively.

A residual level of $1.24 \pm 0.02 \mathrm{mg} \mathrm{kg}^{-1}$ of formaldehyde was noticed in the case of control sample on day 0 and it reached $0.49 \pm 0.02 \mathrm{mg} \mathrm{kg}^{-1}$ on day of rejection ( $12^{\text {th }}$ day). The content of formaldehyde can depend upon fish species and storage conditions (Chanarat and Benjakul, 2013). Formaldehyde content noticed in the control samples can be attributed to the conversion of trimethylamineoxide (TMAO) to formaldehyde and dimethylamine (DMA) and its formation is determined by the duration and temperature of storage (Norliana et al., 2009). Leelapongwattana et al. (2005) reported on the conversion of trimethylamine-N-oxide demethylase (TMAOase) to dimethylamine (DMA) and formaldehyde during ice storage. From food safety point of view, a concentration of $0.2 \mathrm{mg} \mathrm{kg}^{-1}$ body weight per day is considered as maximum daily dose reference (RfD) as per United States Environmental Protection Agency (USEPA, 1999). For an average man of $60 \mathrm{~kg}, 12 \mathrm{mg}$ of formaldehyde can be considered as action dose. The natural production of formaldehyde is $1.24 \mathrm{mg} \mathrm{kg}^{-1}$ in Indian mackerel (Table 1) which decreased to $0.49 \mathrm{mg} \mathrm{kg}^{-1}$ in 12 days of storage. Assuming an average man of $60 \mathrm{~kg}$ consumes $250 \mathrm{~g}$ fish per serving, the formaldehyde contribution to body is $0.31 \mathrm{mg}$ in case of fresh fish. Therefore, the natural level is very insignificant. In the case of fish just after treatment with $0.2,0.5$ and $1 \%$ formaldehyde, the initial level corresponds to $1.9,3.45$ and $5.19 \mathrm{mg}$ respectively per serving $(250 \mathrm{~g})$. A study on health risk assessment in formaldehyde contaminated fish consumption was reported by Siti et al. (2013). Even though it is shown to be less than the action level of $12 \mathrm{mg} \mathrm{kg}^{-1}$ body weight

Table 1. Residual ormaldehyde levels $\left(\mathrm{mg} \mathrm{kg}^{-1}\right)$ in control and treated fish samples during ice storage

\begin{tabular}{lllll}
\hline Days & Control & $0.2 \%$ & $0.5 \%$ & $1 \%$ \\
\hline 0 & $1.24 \pm 0.02^{\mathrm{fA}}$ & $7.61 \pm 0.50^{\mathrm{gB}}$ & $13.83 \pm 2.21^{\mathrm{eC}}$ & $20.75 \pm 2.02^{\mathrm{hD}}$ \\
2 & $0.76 \pm 0.02^{\mathrm{dA}}$ & $3.65 \pm 0.20^{\mathrm{fB}}$ & $5.66 \pm 0.08^{\mathrm{dC}}$ & $15.09 \pm 0.11^{\mathrm{gD}}$ \\
4 & $0.69 \pm 0.04^{\mathrm{cA}}$ & $3.78 \pm 0.20^{\mathrm{fB}}$ & $5.54 \pm 0.30^{\mathrm{dC}}$ & $10.42 \pm 0.28^{\mathrm{fD}}$ \\
6 & $0.57 \pm 0.04^{\mathrm{bA}}$ & $1.12 \pm 0.20^{\mathrm{bcB}}$ & $3.07 \pm 0.20^{\mathrm{cC}}$ & $7.35 \pm 0.28^{\mathrm{eD}}$ \\
8 & $0.60 \pm 0.08^{\mathrm{bA}}$ & $2.10 \pm 0.004^{\mathrm{eB}}$ & $2.01 \pm 0.12^{\mathrm{bcB}}$ & $6.72 \pm 0.38^{\mathrm{eC}}$ \\
10 & $0.86 \pm 0.06^{\mathrm{eA}}$ & $1.40 \pm 0.20^{\mathrm{cB}}$ & $1.75 \pm 0.09^{\mathrm{bC}}$ & $5.11 \pm 0.30^{\mathrm{dD}}$ \\
12 & $0.49 \pm 0.02^{\mathrm{aA}}$ & $1.75 \pm 0.30^{\mathrm{dB}}$ & $1.96 \pm 0.40^{\mathrm{bcB}}$ & $4.41 \pm 0.08^{\mathrm{cdC}}$ \\
14 & & $0.98 \pm 0.20^{\mathrm{bA}}$ & $1.26 \pm 0.20^{\mathrm{abB}}$ & $4.14 \pm 0.10^{\mathrm{cC}}$ \\
16 & & $0.98 \pm 0.001^{\mathrm{abA}}$ & $4.34 \pm 0.18^{\mathrm{cC}}$ \\
18 & & $0.14 \pm 0.003^{\mathrm{aA}}$ & $1.19 \pm 0.30^{\mathrm{bB}}$ \\
20 & & $0.14 \pm 0.09^{\mathrm{dB}}$ & & $0.70 \pm 0.002^{\mathrm{abB}}$ \\
22 & $0.35 \pm 0.30^{\mathrm{aA}}$ & & $0.63 \pm 0.100^{\mathrm{ab}}$ \\
24 & & & $0.42 \pm 0.002^{\mathrm{a}^{*}}$
\end{tabular}

Values are given as Mean \pm SD. Lower case superscript letters indicate significant difference $(p<0.05)$ between storage days $($ column). Upper case superscript letters indicate significant difference $(\mathrm{p}<0.05)$ between storage days (row). "Indicates day of rejection 
for a normal person of average body weight $(60 \mathrm{~kg})$, this amount would be a cause of concern for children and consumers with lesser body weight. Since the exposure of the body to this carcinogenic chemical can lead to minor to serious health problems like vomiting, coma and even death, strict monitoring for the illegal practice of treating seafood with formaldehyde is essential.

\section{Changes in biochemical quality}

pH

The changes in $\mathrm{pH}$ of control and treatment samples are given in Table 2. The live fish muscle $\mathrm{pH}$ is near to 7.0 and it varies from 6.0 to 7.1 post-mortem depending on season, species and other factors. A gradual increase in $\mathrm{pH}$ of control and treated samples during storage was observed during the present study, which might be linked to degradation of samples. Degradation of nitrogenous substances can increase $\mathrm{pH}$ of fish meat (Benjakul et al., 2002). There was no significant difference in $\mathrm{pH}$ between control and treated samples on most of the days of storage. The progress of change in $\mathrm{pH}$ of control samples was faster which reached $6.76 \pm 0.3$ on $12^{\text {th }}$ day of storage. But in treated samples progress of increase was slower and reached $6.95 \pm 0.01$ ( $20^{\text {th }}$ day), $6.92 \pm 0.007\left(20^{\text {th }}\right.$ day $)$ and $7.07 \pm 0.03\left(24^{\text {th }}\right.$ day $)$ in case of $0.2,0.5$ and $1 \%$ treated samples respectively. Variation in $\mathrm{pH}$ can be affected by buffering capacity of meat and formation of inorganic phosphate and ammonia (Sikorski et al., 1990).

\section{Total volatile base nitrogen (TVBN)}

Formation of volatile nitrogen due to the decomposition of protein and non-protein nitrogen compounds is

Table 2. Changes in $\mathrm{pH}$ of control and treated fish samples during ice storage

\begin{tabular}{lllll}
\hline Days & Control & $0.2 \%$ & $0.5 \%$ & $1 \%$ \\
\hline 0 & $6.49 \pm 0^{\mathrm{aA}}$ & $6.48 \pm 0.007^{\mathrm{aB}}$ & $6.48 \pm 0.007^{\mathrm{aB}}$ & $6.45 \pm 0.007^{\mathrm{aB}}$ \\
2 & $6.53 \pm .007^{\mathrm{bC}}$ & $6.50 \pm 0.007^{\mathrm{abB}}$ & $6.50 \pm 0.01^{\mathrm{abB}}$ & $6.46 \pm 0^{\mathrm{abA}}$ \\
4 & $6.54 \pm .007^{\mathrm{bC}}$ & $6.51 \pm 0.02^{\mathrm{bB}}$ & $6.50 \pm 0.007^{\mathrm{abB}}$ & $6.46 \pm 0.007^{\mathrm{abA}}$ \\
6 & $6.55 \pm 0^{\mathrm{cC}}$ & $6.54 \pm 0.03^{\mathrm{cC}}$ & $6.51 \pm 0^{\mathrm{Bb}}$ & $6.48 \pm 0.01^{\mathrm{bA}}$ \\
8 & $6.58 \pm 0^{\mathrm{dB}}$ & $6.57 \pm 0.03^{\mathrm{dB}}$ & $6.52 \pm 0^{\mathrm{Ba}}$ & $6.52 \pm 0.03^{\mathrm{cA}}$ \\
10 & $6.65 \pm .007^{\mathrm{eC}}$ & $6.60 \pm 0.007^{\mathrm{eB}}$ & $6.59 \pm 0.04^{\mathrm{Cb}}$ & $6.53 \pm 0.007^{\mathrm{cA}}$ \\
12 & $6.76 \pm 0.3^{\mathrm{fC} *}$ & $6.67 \pm 0.007^{\mathrm{fB}}$ & $6.61 \pm 0.02^{\mathrm{cA}}$ & $6.67 \pm 0.01^{\mathrm{dB}}$ \\
14 & & $6.70 \pm 0.01^{\mathrm{gA}}$ & $6.71 \pm 0^{\mathrm{Da}}$ & $6.75 \pm 0.01^{\mathrm{eB}}$ \\
16 & $6.73 \pm 0.03^{\mathrm{hA}}$ & $6.73 \pm 0.04^{\mathrm{deA}}$ & $6.79 \pm 0.01^{\mathrm{fB}}$ \\
18 & & $6.76 \pm 0.007^{7^{\mathrm{BB}}}$ & $6.74 \pm 0.04^{\mathrm{eA}}$ & $6.80 \pm 0.007^{\mathrm{fC}}$ \\
20 & $6.95 \pm 0.01^{\mathrm{jC}}$ & $6.92 \pm 0.007^{\mathrm{fB}}$ & $6.85 \pm 0.007^{\mathrm{gA}}$ \\
22 & & & $7.06 \pm 0.03^{\mathrm{h}}$ \\
24 & & & $7.07 \pm 0.03^{\mathrm{h} *}$ \\
\hline
\end{tabular}

Values are given as Mean $\pm \mathrm{SD}$. Lower case superscript letters indicate significant difference $(\mathrm{p}<0.05)$ between storage days $($ column). Upper case superscript letters indicate significant difference $(p<0.05)$ between storage days (row). "Indicates day of rejection

Table 3. Changes in TVBN content of control and treated samples during ice storage

\begin{tabular}{lllll}
\hline Days & Control & $0.2 \%$ & $0.5 \%$ & $1 \%$ \\
\hline 0 & $13.2 \pm 2.94^{\mathrm{aA}}$ & $16.65 \pm 0^{\mathrm{cB}}$ & $18.07 \pm 0^{\mathrm{cB}}$ & $20.17 \pm 0.99^{\mathrm{bcC}}$ \\
2 & $14.57 \pm .98^{\mathrm{aA}}$ & $16.03 \pm 0.99^{\mathrm{cB}}$ & $18.74 \pm 0.99^{\mathrm{cdC}}$ & $20.19 \pm 0.99^{\mathrm{bcD}}$ \\
4 & $15.29 \pm 1.96^{\mathrm{aA}}$ & $19.58 \pm 0^{\mathrm{dB}}$ & $20.21 \pm 0.98^{\mathrm{deB}}$ & $23.05 \pm 0.99^{\mathrm{cdC}}$ \\
6 & $20.95 \pm 0^{\mathrm{eA}}$ & $24.5 \pm 0.98^{\mathrm{fB}}$ & $25.09 \pm 1.98^{\mathrm{deB}}$ \\
8 & $21.52 \pm 0.98^{\mathrm{bA}}$ & $22.26 \pm 0^{\mathrm{fA}}$ & $24.89 \pm 0^{\mathrm{BB}}$ & $25.07 \pm 0^{\mathrm{BB}}$ \\
10 & $25.75 \pm 1^{\mathrm{cC}}$ & $22.35 \pm 0^{\mathrm{fA}}$ & $25.6 \pm 0^{\mathrm{BB}}$ & $27.83 \pm 0^{\mathrm{eC}}$ \\
12 & $29.25 \pm 1.97^{\mathrm{dD}}$ & $28.7 \pm 0.98^{\mathrm{gA}}$ & $32.79 \pm 2.96^{\mathrm{gB}}$ & $33.33 \pm 0^{\mathrm{Fb}}$ \\
14 & $40.47 \pm 1.97^{\mathrm{eA}}$ & $20.95 \pm 1.98^{\mathrm{eA}}$ & $21.63 \pm 0.98^{\mathrm{eB}}$ & $26.54 \pm 1.97^{\mathrm{deB}}$ \\
16 & $7.68 \pm 0.98^{\mathrm{bA}}$ & $15.38 \pm 1.98^{\mathrm{bA}}$ & $18.12 \pm 0.99^{\mathrm{bB}}$ \\
18 & $5.58 \pm 0^{\mathrm{aAB}}$ & $4.87 \pm 0.99^{\mathrm{aA}}$ & $6.28 \pm 0.99^{\mathrm{aB}}$ \\
20 & $4.88 \pm 0.99^{\mathrm{aA}}$ & $4.20 \pm 0^{\mathrm{aA}}$ & $6.95 \pm 0^{\mathrm{Ab}}$ \\
22 & & & $5.58 \pm 0^{\mathrm{a}}$ \\
24 & & & $4.32 \pm 0^{\mathrm{a}^{*}}$ \\
\hline
\end{tabular}

Values are given as Mean \pm SD. Lower case superscript letters indicate significant differences $(p<0.05)$ between storage days (column). Upper case superscript letters indicate significant differences $(\mathrm{p}<0.05)$ between storage days (row). "Indicates day of rejection 
mainly because of microbial action and it goes up along with storage period. Generally, it is lesser at acceptable stage and reaches higher levels at rejection. A level of $30-35 \mathrm{mg} \%$ is set as the acceptability limit (Lakshmanan et al., 1990). Changes in TVBN value of control and formaldehyde treated samples on alternate days are given in Table 3.

Statistically significant difference $(\mathrm{p}<0.05)$ between TVBN values of control and treatment samples during storage was noticed. In control, the increase was progressive, reaching a maximum $(40.47 \mathrm{mg} \%)$ on $12^{\text {th }}$ day. TVBN value of tilapia (Oreochromis niloticus) outlined a slight gain in value in the initial days and it progressed fast towards later stages during ambient conditions due to microbial action (Adoga et al., 2010). Connel (1995) reported that the TVBN in freshly caught fish is typically between 5 and $20 \mathrm{mg} \mathrm{N} 100 \mathrm{~g}^{-1}$. TVBN values of treated samples during the present study showed a maximum value on the $12^{\text {th }}$ day followed by a statistically significant $(p<0.05)$ decrease during remaining days. The decrease in TVBN value can be due to the leaching out of volatile amines like ammonia along with ice melt water (Oehlenschlager, 1997). Mehta and Shamasundar (2015) reported a decrease in TVBN content at the end of ice storage of Cirrhinus mrigala.

Changes in microbial quality - Aerobic plate count

A substantial change in microbial load can occur during chilled storage of fishes. Presence of formaldehyde can significantly affect the microbial load due to its bactericidal action. Aerobic plate count of control and formaldehyde treated samples is given in Fig. 1. Mesophilic aerobic plate count of fresh mackerel was $4 \log \mathrm{cfu} \mathrm{g}^{-1}$ which decreased to $2.43,2.04$ and $1.5 \mathrm{log} \mathrm{cfu} \mathrm{g}^{-1}$ after treatment with $0.2,0.5$ and $1 \%$ formaldehyde respectively, indicating the bactericidal action of formaldehyde. Dipping seafood in formaldehyde solution for a specific period can prevent spoilage and increase storage time (Wilbur et al., 1999). The initial decrease of APC in control samples can be due

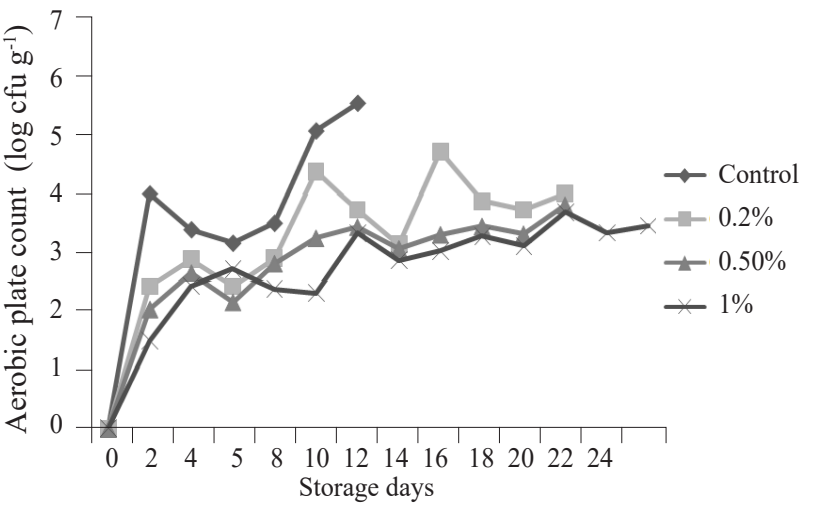

Fig. 1. Aerobic bacterial count of control and formaldehyde treated samples to cold shock reaction or leach out of surface bacteria with melt water. On the $10^{\text {th }}$ day of storage the bacterial counts of control samples reached $5.54 \log \mathrm{cfu} \mathrm{g}^{-1}$, where as the bacterial load of treated samples were much lower on the $10^{\text {th }}$ day of storage. Bacterial count in control increased to $6 \log \mathrm{cfu} \mathrm{g}^{-1}$ on $16^{\text {th }}$ day. According to International Commission on Microbiological Specification for Food (ICMSF, 1986) the flesh APC should not exceed $10^{6} \mathrm{cfu} \mathrm{g}^{-1}$. The aerobic counts were lowest in $1 \%$ formaldehyde treated sample compared to others. Counts of 0.2 and $0.5 \%$ treated samples did not show much difference. Yeasmin et al. (2010) reported comparable results showing a significant decrease in bacterial growth in formaldehyde treated rohu during ice storage. Microorganisms are present on the skin, gills and gut of fish which will gradually invade the flesh after death. But dipping in formaldehyde might significantly reduce the microbial load on the external surfaces like skin and gills due to its bactericidal property. As a result, the number of microbes invading the flesh and subsequent spoilage gets reduced. Shelf life of 0.2 and $0.5 \%$ treated samples got extended to 8 more days and $1 \%$ treated samples extended to 12 more days. Neely (1963) reported that 20 to $50 \mu \mathrm{g}$ or $2-5 \%$ formaldehyde can prohibit bacterial cell division. Results of the present study is in compliance with the reports of Mol et al. (2007) on shelf life estimation in ice stored fresh anchovy, horse mackerel, cod and rainbow trout.

\section{Sensory quality}

Sensory evaluation being a subjective method can be best coupled with other methods to form an important quality index. It is the most reliable test for raw material and processed fishery products. The sensory evaluation was conducted in the control and treated samples on alternate days during the study period. Variation in sensory attributes can affect consumers' acceptance. Sensory changes of control and formaldehyde treated samples recorded during the present study are depicted in Fig. 2.

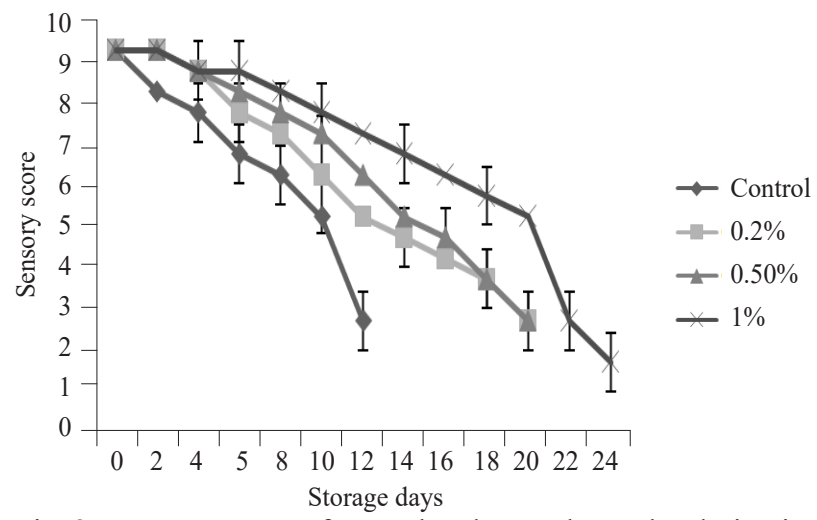

Fig. 2. Sensory score of control and treated samples during ice storage 
The control samples were rejected by the sensory panel on $12^{\text {th }}$ day when the overall acceptability score given by the sensory panel members was below 4, TVBN of $25.52 \mathrm{mg} \%$ and APC crossed $5 \log \mathrm{cfu}^{-1}$. The formaldehyde treated samples appeared fresh without any visible spoilage changes even after the day of rejection of control samples. During the initial two days of sampling, the treated samples were observed to have a pungent odour. Leaching out of ice melt water drained away the formaldehyde residues and as a result the sensory panel couldn't identify the odour due to chemical treatment in the subsequent days. The belly wall of treated samples was firm and didn't rupture during ice storage. The eyes of the treated samples became fully cloudy, sunken and not visible after 12 days of storage. Texture of control as well as 0.2 and $0.5 \%$ treated samples were almost similar just after the treatment, while the $1 \%$ treated sample was superior in texture to control. During ice storage, the texture quality score decreased in all the samples, with a comparatively better texture quality observed in $1 \%$ treated samlpes. Gills of treated samples were dark red in colour, but without any specific spoilage smell. The 0.2 and $0.5 \%$ formaldehyde treated samples were rejected by the sensory panel on the $20^{\text {th }}$ day and $1 \%$ treated sample on the $24^{\text {th }}$ day of storage. Shelf life of samples was determined based on sensory evaluation for all the samples. A shelf life of 10 days was observed in case of control where the TVBN reached above $40 \mathrm{mg} \%$ and APC was within the acceptable limit. The shelf life observed for 0.2 and $0.5 \%$ formaldehyde treated samples was 18 days and that of $1 \%$ treated samples was 22 days.

Consumer acceptance is very much related to freshness. The retailers can significantly influence the consumer's perception of quality. Appearance of fresh condition of formaldehyde treated fish can mislead the consumers and they will find it difficult to separate and identify the treated fish from untreated fish. The bactericidal nature of toxic formaldehyde can delay spoilage of fish, but definitely cause threat to consumers. Since the natural level of formaldehyde varies between species, information on natural levels during ice storage of common marketed fishes needs to be generated. Evaluation of formaldehyde level in comparison to natural formaldehyde formation in fish meat along with assessment of microbial and biochemical indices can distinguish formalin treated and untreated fishes. Illegal usage of formaldehyde in treating fishes marketed for consumption should be prevented as it can pose potential and fatal health problems to consumers.

\section{Acknowledgements}

This research work was completed with the support of Indian Council of Agricultural Research, New Delhi, India. The authors thank the Director, ICAR-CIFT, Kochi for extending research facilities.

\section{References}

Adoga, I. J., Joseph, E. and Samuel, O. F. 2010. Storage life of tilapia (Oreochromis niloticus) in ice and ambient temperature. Researcher, 2(5): 39-44.

Amerine, M. A., Pongborn, R. H. and Roescler, E. B. 1965. Principles of sensory evaluation of food. Academic, New York, p 602.

AOAC 1990. Official methods of analysis, $15^{\text {th }}$ edn. Association of Official Analytical Chemists, Washington DC, USA

Badii, F. and Howell, N. K. 2002. Changes in the texture and structure of cod and haddock fillets during frozen storage. Food Hydrocol., 16: 313-319.

Benjakul, S., Visessanguan, W., Reibrou, S., Ishizaki, S. and Tanaka, M. 2002. Gel forming properties of surimi produced from bigeye snapper, Priacanthus tayenus and P. macracanthus, stored in ice. J. Sci. Food Agr., 82(13): 1442-1451.

Bianchi, F., Careri, M., Musci, M. and Mangia, A. 2007. Fish and food safety: Determination of formaldehyde in 12 fish species by SPME extraction and GC-MS analysis. Food Chem., 100: 1049-1053.

Castell, C. H. and Smith, B. 1973. Measurement of formaldehyde in fish muscle using TCA extraction and the Nash reagent. J. Fish. Res. Board Can., 30: 91-98.

Chanarat, S. and Benjakul, S. 2013. Effect of formaldehyde on protein cross linking and gel forming ability of surimi from lizardfish induced by microbial transglutaminase. Food Hydrocoll., 30: 704-711.

Connel, J. J. 1995. Control of fish quality. Fishing News Books, Blackwell Science Ltd, Cambridge, London, p. 241.

Conway, E. J. 1950. Micro-diffusion analysis and volumetric error. Crosby Lockwood and Son Ltd., London.

EFSA 2014. Endogenous formaldehyde turnover in humans compared with exogenous contribution from food sources. EFSA Journal, 12(2):3550. doi:10.2903/j.efsa.2014.3550

FAO 2009. World review of fisheries and aquaculture. In: The state of world fisheries and aquaculture, Food and Agriculture Organization, Rome, Italy.

ICMSF 1986. Microorganisms in foods, sampling for microbiological analysis: principles and specific applications, $2^{\text {nd }}$ edn. International Commission on Microbiological Specifications for Foods.

Khan, M. N. A., Islam, M. N. and Reza, M. S. 2009. Investigation on the nitrofuran and their metabolites and chemicals used in shrimp feeds and feed ingredients: Final report for Bangladesh quality support program (BQSP)-fisheries, UNIDO, Project No: $E E / B G D / 05 / B 02$, p. 5-6.

Lakshmanan, P. T., Varma, P. R. G., Iyer, T. S. G. and Gopakumar, K. 1990. Quality changes in frozen whole and filleted rock cod (Epinephelus spp.) during storage. Fish. Res., 9: 1-12. 
Leelapongwattana, A., Benjakul, S., Visessanguan, W. and Howell, N. K. 2005. Physicochemical and biochemical changes during frozen storage of minced flesh of lizardfish (Saurida micropectoralis). Food Chem., 90: 141-150.

Mehta, N. K. and Shamasundar, B. A. 2015. Changes in chemical and sensory properties of freshwater fish (Indian major carps) during ice storage. Prog. Agric, 16(1): 77-82.

Mol, S., Erkan, N., Ucok, D. and Tosun, Y. 2007. Effect of psychrophilic bacteria to estimate fish quality. J. Muscle Foods, 18(1): 120-128.

Neely, W. B. 1963. Action of formaldehyde on microorganisms-I. Correlation of activity with formaldehyde metabolism J. Bacteriol., 85: 1028-1031.

Noordiana, N., Fatimah, A. B. and Farhana, Y. C. B. 2011. Formaldehyde content and quality characteristics of selected fish and seafood from wet markets. Int. Food Res. J., 18: 125-136.

Norliana, S., Abdulamir, S., Abu Bakar, F. R. and Salleh. 2009. The health risk of formaldehyde to human beings. Am. J. Pharmacol. Toxicol., 4(3): 98-106.

Oehlenschlager, J. 1997. Volatile amines as freshness/spoilage indicators. A literature review. In: Luten, J. B., Borrensen, T. and Oehlenschlager, J. (Eds.), Seafood from producer to consumer, Integrated approach to quality. Elsevier, Amsterdam, p. 571-584

Sikorski, R. S., Boguski, M. S., Goebl, M. and Hieter, P. 1990. A repeating amino acid motif in $\mathrm{CDC} 23$ defines a family of proteins and a new relationship among genes required for mitosis and RNA synthesis. Cell, 60(2): 307-317.
Simeonidou, S., Govaris, A. and Vareltzis, K. 1998. Quality assessment of seven Mediterranean fish species during storage on ice. Food Res. Int., 30(1): 479-484.

Siti, A. A., Zalina, H. and Fatimah, A. B. 2013. Health risk assessment of adults consuming commercial fish contaminated with formaldehyde. Food Pub. Health., 3(1): 52-58.

Tsuda, M., Frank, N., Sato, S. and Sugimura, T. 1988. Marked increase in the urinary level of N-nitrosothioproline after ingestion of cod with vegetables. Cancer Res., 48(14): 4049-4052.

USEPA 1999. US Environmental Protection Agency Integrated Risk Information System (IRIS) on formaldehyde. National Center for Environmental Assessment, Office of Research and Development, Washington, DC, USA.

USFDA. 2001. Bacteriological analytical manual, $8^{\text {th }}$ edn., Revision A. In: Benett, R. W. and Lancett, G. A. (Eds.), United States Food and Drugs Administration, Rockville, MD, USA.

Wang, S., Cui, X. and Fang, G. 2007. Rapid determination of formaldehyde and sulphur dioxide in food products and Chinese herbals. Food Chem., 103: 1487-1493.

Wilbur, S., Harris, M. O., Cllure, P. R. M. and Spoo, W. 1999. Toxicology profile of formaldehyde. US Department of Health and Service (DHHS), USA

Yeasmin, T., Reza, M. S., Shikha, F. H., Khan, M. N. A. and Kamal, M. 2010. Quality changes in formalin treated rohu fish (Labeo rohita, Hamilton) during ice storage condition, Asian J. Agri. Sci., 2(4): 158-163.

Yeasmin, T., Reza, M. S., Shikha, F. H., Khan, M. N. A. and Kamal, M. 2013. Effect of washing and chilled storage on the retention of formalin and quality of rohu fish (Labeo rohita, Hamilton). J. Agri. Food Sci., 1(6): 118-122. 